\title{
Spatial analysis of the trophic interactions between two juvenile fish species and their preys along a coastal-estuarine gradient
}

\author{
Dorothée Kopp ${ }^{\mathrm{a}, *}$, Hervé Le Bris ${ }^{\mathrm{b}}$, Lucille Grimaud ${ }^{\mathrm{a}}$, Caroline Nérot ${ }^{\mathrm{c}}$, Anik Brind'Amour ${ }^{\mathrm{a}}$
}

\begin{abstract}
a IFREMER, Unité Ecologie et Modèles pour l'Halieutique, Rue de l'île d'Yeu, B.P. 21105, 44311 Nantes Cedex 03, France

${ }^{\mathrm{b}}$ Université Européenne de Bretagne, Agrocampus Ouest, UMR 985, 65 rue de St. Brieuc, CS 84215, 35042 Rennes Cedex, France

${ }^{c}$ LEMAR, UMR CNRS/UBO/IRD 6539, Institut Universitaire Européen de la Mer, Place Nicolas Copernic, 29280 Plouzané, France
\end{abstract}

\author{
*: Corresponding author : Dorothé Kopp, tel.: + 33240374160 ; fax: + 33240374075 ; \\ email address : koppdorothee@gmail.com
}

\begin{abstract}
:
Coastal and estuarine systems provide nursery grounds for many marine fish species. Their productivity has been correlated with terrigeneous inputs entering the coastal-estuarine benthic food web, thereby favouring the establishment of fish juveniles. Studies in these ecosystems often describe the nursery as a single large habitat without verifying nor considering the presence of contiguous habitats. Our study aimed at identifying different habitats based on macrozoobenthic communities and morpho-sedimentary characteristics and assessing the trophic interactions between fish juveniles and their benthic preys within these habitats. It included 43 sampling sites covering 5 habitats in which we described taxonomically and quantitatively the invertebrates and fish communities with stable isotopes and gut contents. It suggested that the benthic common sole Solea solea displayed feeding plasticity at the population level, separating the juveniles (G0) from the older fish (G1) into different "feeding sub-populations". Size-based feeding plasticity was also observable in the spatial occupancy of that species in the studied bay. The demersal pouting, Trisopterus luscus, equally used the different habitats but displayed low feeding plasticity across and inside each habitat. Stable isotopes proved to be powerful tools to study the spatial distribution of trophic interactions in complex ecosystems like the bay of Vilaine and to define optimal habitats for fish that use the coastal-estuarine ecosystem as nursery grounds.
\end{abstract}

\section{Highlights}

Identification of habitats based on benthic macrofauna and morpho-sedimentary data. Assessment of trophic interactions between juveniles fish and their preys. Juveniles of sole displayed size-based feeding plasticity according to habitats. Juveniles of pouting equally used the different habitats.

Keywords: Stable isotopes ; Gut content ; Food web ; Nursery ground ; Solea solea ; Trisopterus luscus 


\section{Introduction}

Located at the sea-continent interface, coastal ecosystems are known as productive areas (Costanza et al., 1997). They foster high primary and secondary production (Largier, 1993) and sometimes tertiary production as they are inhabited by marine species at various stages of their life cycle (Beck et al., 2001). Coastal zones are characterized by local production and inputs of organic matter originating from different sources (e.g. detritic, algal, planktonic) which vary greatly in time and space. These inputs may considerably boost up the coastal and marine production (Maslowski, 2003) and may significantly modify ecosystem functioning (Baird et al., 2004). For instance, seasonal river floods result in an increase in input of macronutrients leading to an increase in plankton production (Nielsen and Richardson, 1996). Benthic production also varies at various temporal scales via the cycling of nutrients between the sediments at the bottom and the overlying water column (Josefson and Conley, 1997). Nutrient enrichment and eventually eutrophication resulting from the pelagic-benthic coupling has a noticeable impact on food availability to the benthic fauna (Darnaude et al., 2004a). The impact of nutrient enrichment on the fluctuation of species abundance in coastal marine communities can be of prime importance in the functioning of these ecosystems (Salen-Picard et al., 2002). Thus terrestrial organic matter has been shown to play a significant role in the dynamics of coastal macrobenthic communities and on the productivity of commercial fish species and fisheries (Darnaude et al., 2004b).

Research on essential coastal habitats, such as nurseries, often describes them as a single large habitat without considering that it is composed of a mosaic of habitats (i.e. seascape) that provides resources for a diversity of species (Ray, 2005). Generally, when more than one habitat is studied, these are examined separately so that little is known about how they interact 
and function together. The complexity of the spatial organisation of these habitats and the multiplicity of potential organic matter sources that support secondary and tertiary consumers, make fairly challenging the study of the nursery functioning (Deegan and Garritt, 1997).

Stable isotopes tracking is a powerful tool to apprehend the functional aspects of a nursery's spatial organisation, yet allowing the definition of optimal habitats for fish species that use the coastal-estuarine ecosystem as nursery grounds. Basic rationale of the stable isotopes approach is that the isotopic composition of consumer tissues reflects this of their diet, which in turn depends on the relative proportions of prey species assimilated over a specific time period (De Niro and Epstein, 1978; Minagawa and Wada, 1984; Peterson and Fry, 1987). Stable isotopes of carbon and nitrogen are commonly used to examine consumers' trophic ecology providing a time-integrated measure of trophic position and energy sources. Nitrogen stable isotope ratios in consumers are typically enriched in the heavier $\left({ }^{15} \mathrm{~N}\right)$ isotope by from 2 to $4 \%$ per trophic level (Minagawa and Wada, 1984; Peterson and Fry, 1987), making $\delta^{15} \mathrm{~N}$ values useful in defining trophic positions of consumers (Post, 2002). The carbon isotope ratios fractionate to a lesser extent (0 to $1 \%$ o) and are typically used to define diet compositions or sources of energy (De Niro and Epstein, 1978).

In estuarine-coastal gradients, the natural variations of stable isotopes allow to distinguish coastal from marine areas either on $\delta^{15} \mathrm{~N}$ or $\delta^{13} \mathrm{C}$. Terrestrial and estuarine waters traditionally present ${ }^{13} \mathrm{C}$-depleted values compared to marine waters because carbon in materials originated by photosynthesis (e.g. fixed carbon in terrestrial plants or phytoplankton) is depleted in ${ }^{13} \mathrm{C}$ compared to atmospheric $\mathrm{CO}_{2}$. Seawater $\delta^{13} \mathrm{C}$ is supposedly at equilibrium with atmospheric $\mathrm{CO}_{2}$ (Oana and Deevey, 1960). In the same way, terrestrial waters have traditionally lower $\delta^{15} \mathrm{~N}$ than marine waters (France, 1995), but nowadays, higher values in $\delta^{15} \mathrm{~N}$ are often 
observed in coastal waters in comparison to marine waters, as coastal ecosystems receive ${ }^{15} \mathrm{~N}$ enriched sewage discharges (anthropisation, agriculture and industries) with river run-offs (Gartner et al., 2002; Schlacher et al., 2005). According to McClelland et al. (1997), wastewater with high $\mathrm{NO}_{3}{ }^{-}$derived from human and animal wastes is ${ }^{15} \mathrm{~N}$ enriched $(+10$ to $+20 \%$ ) and elevates the overall $\delta^{15} \mathrm{~N}$ signatures of water entering the trophic chain in coastal areas. These variations of stable isotope signatures along seaward gradient, make stable isotopes useful in the identification of the primary sources of organic carbon in the diet of organisms. In such conditions, the isotopic approach has been successfully used to trace the transfer of organic matter through estuarine and coastal food webs (Islam and Tanaka, 2006; Vinagre et al., 2008) and identify aspects of life history or movement patterns of species in nursery habitats (Fry, 2008). Stable isotope ratios $\left(\delta^{15} \mathrm{~N}\right.$ or $\left.\delta^{13} \mathrm{C}\right)$ were recently used in coastal areas to infer on the relative contribution of different resources use among juveniles of flatfish species (Vinagre et al., 2008; Kostecki et al., 2010; Le Pape et al., 2012) and to quantify the relative contribution of estuarine and coastal production in supporting juveniles fish (Leakey et al., 2008b). They have also proved to be powerful tools to assess ontogenetic size-based shift in fish diet and associated feeding plasticity (e.g. Leakey et al., 2008a for age 1+, 2+ and 3+ common sole; Ho et al., 2009).

The present study aimed to answer the following questions: Do juveniles of benthic and demersal fish species use the bay of Vilaine as one large habitat or as multiple habitats? If so, do these habitats display the same trophic interactions? In order to answer these questions, we defined and assessed the spatial organization of habitats along the estuarine-coastal gradient of the bay of Vilaine nursery ground. More precisely, we (i) identified different habitats based on macrozoobenthic communities and morpho-sedimentary characteristics, (ii) described and tested the biological and ecological differences of these biosedimentary habitats using stable 
isotope analyses and fish stomach contents, and (iii) assessed the trophic interactions within these habitats. We hypothesized that benthic species would be more constrained in their use of habitats due to their close relationships with the substrate and associated fauna compared to demersal fish. In the same way we expected that age-0 fish (G0), due to a high site fidelity, would present lower feeding plasticity than older individuals (G1).

\section{Material and methods}

\subsection{Study area and sampling protocol}

The study was conducted in the bay of Vilaine located on the French Atlantic coast, south

Brittany (Fig. 1). The bay covers a surface area of $230 \mathrm{~km}^{2}$ and is characterized by an open

130 shallow muddy estuarine area, under the influence of freshwater inflows. Surveys were carried out at the end of August 2008 using a stratified sampling design relying on a 5-stratum scheme (Fig. 1), in which each stratum was identified by depth range and sediment type. Depths ranged from 5 to $35 \mathrm{~m}$ and the sediment types varied from coarse-grained sand and

134 gravel to fine sand and/or coarse silt. Sampling was conducted using a $2.9 \mathrm{~m}$ wide and $0.5 \mathrm{~m}$

135 high beam trawl, with a 20-mm-stretched mesh net in the cod-end. Each haul lasted 15 min 136 and covered a mean surface of $4500-5000 \mathrm{~m}^{2}$. A total of 43 hauls were performed (Fig. 1, see 137 Table 1 for the number of hauls by habitat).

138 All fish were identified at the species level and weighted. This study focused however on two 139 of the most abundant species in the bay of Vilaine: the benthic common sole and the demersal 140 pouting. Individuals from these two species were aged according to their length-frequency 141 distributions. The two size-classes corresponded respectively to the young-of-the-year group 142 (G0) and age one group (G1): common sole (G0: $9.09 \pm 0.76 \mathrm{~cm}, \mathrm{G} 1: 16.45 \pm 1.25 \mathrm{~cm}$ ) and 143 pouting (G0: $7.88 \pm 0.96 \mathrm{~cm}, \mathrm{G} 1: 11.49 \pm 0.93 \mathrm{~cm}$ ). These size classes were consistent with 
144 our own database of otolith measures (unpublished data) and other studies (Merayo and

145 Villegas, 1994; Mérigot et al., 2007). As several studies have highlighted the nursery function

146 of the bay of Vilaine for these two species (Le Pape et al., 2003b), yet only the two size

147 classes associated with the juvenile phase were studied. Individuals of the two species were

148 frozen $\left(-24^{\circ} \mathrm{C}\right)$ prior to isotopic and gut content analyses.

149

150 Concurrently, the benthic fauna was sampled at the same sites (43 sampling sites with 4 151 replicates per site) using a Van Veen grab $\left(0.1 \mathrm{~m}^{2}\right)$. Sediments from the grab were sieved in a 152 cubic screen (1 mm mesh size). Retained fraction (sediments and macro-invertebrates) of 3 of 153 the 4 replicates was fixed and preserved in 10\% seawater buffered formaldehyde. The 154 remaining grab replicate was frozen $\left(-24^{\circ} \mathrm{C}\right)$ for isotopic analyses. In the laboratory, 155 invertebrates were sorted from the sediments and identified to the lowest taxonomic level, 156 before counting and weighing. Analyses of the benthic fauna were conducted on the summed 157 biomass of the 3 replicates by site. Benthic invertebrate macrofauna was categorized into 158 trophic guilds for the comparison between the habitats: carnivores, detritivores, deposit- and 159 suspension-feeders (Fauchald and Jumars, 1979; Rosenberg, 1993; Hily and Bouteille, 1999;

160 Appeltans et al., 2011). Bottom water was sampled using a Niskin bottle and filtered until 161 clogged through precombusted Whatman GF/F filters $(0.5 \mu \mathrm{m})$ immediately after sampling. 162 Filters were kept frozen until their extraction to obtain particulate organic matter (POM).

164 2.2. Stable isotope analyses (SIA)

165 A sample of white dorsal muscle of the fish was dissected and used for SIA (Pinnegar and 166 Polunin, 1999). All samples were frozen individually at $-80^{\circ} \mathrm{C}$ before freeze-drying. Each 167 dried sample was then ground into a homogeneous powder using a mixer mill. Approximately $168 \quad 0.2 \mathrm{mg}$ of sample was accurately weighed into small tin cups, and stable isotope ratios of 
carbon and nitrogen were analysed in a Carlo Erba NC2500 elemental analyser coupled to a Thermo Finnigan Mat Delta XP isotope ratio mass spectrometer. Isotope ratios were reported in delta notation as per international standards: Pee Dee belemnite carbonate for $\delta^{13} \mathrm{C}$ and atmospheric nitrogen for $\delta^{15} \mathrm{~N}$. Data were corrected using working standards (bass muscle, bovine liver, nicotinamide; $\mathrm{SD}<0.2 \%$ for both $\delta^{13} \mathrm{C}$ and $\left.\delta^{15} \mathrm{~N}\right)$ that were previously calibrated against International Atomic Energy Agency (IAEA) standards.

Benthic invertebrates selected for SIA were those considered as potential preys for the bentho-demersal fish species and dominant in terms of abundance and biomass in the Vilaine coastal-estuarine ecosystem. Isotope analyses were conducted on the muscle of large benthic organisms (i.e. $>1 \mathrm{~cm}$ ), whereas analyses were done on the remaining tissues once the digestive tracts, jaws and cerci were removed for small organisms. Remaining tissues were then washed with distilled water in order to prevent any contamination by sediment carbonates. Samples of small invertebrates (e.g. bivalve juveniles, crustaceans, ophiurids) were divided into 2 subsamples: 1 subsample, for carbon isotope analysis, was acidified with $1 \% \mathrm{HCl}$ solution to remove carbonates and rinsed with distilled water as carbonates present higher $\delta^{13} \mathrm{C}$ values than organic carbon (De Niro and Epstein, 1978). The other subsample, for nitrogen isotope analysis, was not acidified since acidification results in enrichment of $\delta^{15} \mathrm{~N}$ (Pinnegar and Polunin, 1999). In many cases, several individuals of the same species at a given site had to be pooled to have sufficient biomass for SIA ( $0.2 \mathrm{mg}$ of dried tissue). Preys were classified in the same trophic guilds as those used for the grab-sampled benthic macrofauna (Fauchald and Jumars, 1979; Rosenberg, 1993; Hily and Bouteille, 1999; Appeltans et al., 2011). Whatman GF/F filters containing particulate organic matter (POM) were oven-dried and subsequently exposed to $\mathrm{HCl}$ vapour for 4 hours in order to remove the carbonates (Lorrain et al., 2003). All stable isotope analyses were performed at the Stable 
194

195

196

197

198

199

200

201

202

203

204

205

206

207

208

209

210

211

212

213

214

215

216

217

Isotopes in Nature Laboratory, University of New Brunswick, Canada. Number of samples analysed for SIA are given in Fig.2.

For invertebrate tissues, the observed C: $\mathrm{N}$ ratios were sometimes greater than 3.5 , the value above which lipid normalization is recommended (Post et al., 2007). To account for the influence of lipid content on the $\delta^{13} \mathrm{C}$, mathematical delipidation was performed after analysis using the following equation (Post et al., 2007):

$\delta^{13} \mathrm{C}_{\text {normalized }}=\delta^{13} \mathrm{C}_{\text {untreated }}-3.32+0.99 \times \mathrm{C}: \mathrm{N}$

As $\delta^{15} \mathrm{~N}$ values provide indication of the trophic position (TP) of a consumer, TP for all prey and fish were calculated following Post equation (Post, 2002):

$\mathrm{TP}=\left(\delta^{15} \mathrm{~N}\right.$ consumer $-\delta^{15}$ Nbase $) / \Delta$

where $\Delta$ is the assumed trophic-enrichment factor for $\delta^{15} \mathrm{~N}$ values, estimated at 3.4\%o (Minagawa and Wada, 1984). In each habitat, the $\delta^{15} \mathrm{~N}$ base referred to the lowest available $\delta^{15} \mathrm{~N}$ value, i.e. that of the particulate organic matter.

\subsection{Gut content analyses}

To assess the composition of fish diet, the gut contents of 89 common soles and 132 poutings were analysed. All prey items were identified to the highest possible taxonomic level, sorted and counted under a binocular microscope. The use of prey counts instead of prey biomass was preferred to avoid the bias (i.e. overestimation) potentially induced by preys that are partially ingested by juvenile fish (e.g. bivalve siphons). Prey items in gut contents were classified in the same trophic guilds as those used for the grab-sampled benthic macrofauna and SIA. Numbers of analysed gut contents are given in Fig.3. 


\subsection{Statistical analysis}

219 A common approach to cope with biotic patterns is to select sampling sites along explicit gradients, such as depth and substrate gradients. That strategy is very much like using a stratified sampling in which the strata define habitat patches, and multiple samples within them are treated as approximate replicates, meaning, in practice, that samples within habitat patches are expected to be more similar than samples from different patches. This is the strategy that we have used to identify and characterize the spatial patterns of the benthodemersal community in the bay of Vilaine. We identified habitat patches using Ward's hierarchical clustering analyses (Ward Jr, 1963) calculated on the Bray Curtis dissimilarity coefficient of the sites-species matrix. The latter was composed of macrobenthic biomass and morpho-sedimentary data (bathymetry, sediment type and organic matter). The Bray Curtis coefficient was chosen as it is acknowledged to be a good measure of ecological distance for species data (Faith et al., 1987). The number of clusters (i.e. habitat patches) was visually assessed and confirmed using the simple structure index SSI (Dolcinar et al., 1999).

Quantitative description of each habitat was done by estimating and comparing diverse 234 indices (biomass, Simpson's diversity index, guild biomass) and isotopic signatures $\left(\delta^{13} \mathrm{C}\right.$, $235 \delta^{15} \mathrm{~N}$ ) of the POM, benthic preys, and fish. As the number of grabs slightly differed between 236 habitats, we preferred the inverse Simpson's index over other measures of diversity: 237 Simpson's index being less vulnerable to sampling effort (Buckland et al., 2005; Colwell, 238 2009). That index estimates the likelihood that two species selected randomly from the 239 different habitats would be different species. We defined $\mathrm{p}_{\mathrm{ij}}=\mathrm{d}_{\mathrm{ij}} / \Sigma_{\mathrm{i}} \mathrm{d}_{\mathrm{ij}}$ to be the proportion of 240 individuals present in site ${ }_{\mathrm{j}}$ that belong to species ${ }_{\mathrm{i}}$. Simpson's index (D) for site ${ }_{\mathrm{j}}$ is then $_{\mathrm{Dj}_{\mathrm{j}}}=$ $241 \Sigma_{\mathrm{i}} \mathrm{p}_{\mathrm{ij}}{ }^{2}$. For convenience, we used the transformed Simpson's index $-\ln \mathrm{D}_{\mathrm{j}}$ such that high values 
244 The indices and the isotopic signatures of the POM and benthic preys were compared between

245 (previously defined) habitat patches using non-parametric permutation-based one-way 246 ANOVA using habitat as a fixed factor. Permutation procedures were used as the assumption 247 of the normality of residuals was almost always violated. As isotopic signatures may vary 248 according to fish size (Brischoux et al., 2010), comparison of the fish isotopic signatures was 249 conducted using two-way permutation-based analyses of variance with habitat and fish size classes as fixed factors. The interaction of the habitat and fish size was also tested. Yet, the sole and pouting were classified in young-of-the-year (G0) and age-one group (G1). When significant differences were found, multiple comparison tests (i.e. Conover-Inman nonparametric multiple pairwise comparison test) were conducted (Conover, 1999).

Comparison of the fish gut contents between the different habitats was done using distancebased multivariate analyses of variance (MANOVA) with permutations (Anderson, 2001). A two-way design was used, testing the effect of habitat and fish size classes as well as the habitat*size interaction. Distance-based MANOVA is highly similar to its parametric univariate counterpart (ANOVA) in that it uses a multivariate analogue to the Fisher's F-ratio calculated directly from any distance or dissimilarity matrix. In practice, preys abundance from the gut contents of the sole and the pouting were grouped and summed in trophic guilds (i.e. invertebrate carnivores, detritivores, deposit- and suspension-feeders). Matrices of prey guilds were then transformed in distance matrices using Bray-Curtis pairwise distance 263 (double-root transformation). The test was done using unrestricted permutation of raw data 264 (Gonzalez and Manly, 1998) with 4999 random permutations on the full model. Data analyses 265 and statistical tests were implemented using R software (2008) and a significant threshold of 0.05 was used. 


\section{Results}

\subsection{Habitats along the coastal-estuarine gradient}

271 Cluster analyses computed on the biomass of the benthic macrofauna combined with morpho272 sedimentary data detected five groups of sites along the coastal-estuarine gradient (Fig. 1), 273 hereafter defined as Habitat 1 (H1) to Habitat 5 (H5). These habitats differed in terms of 274 biotic (i.e. species assemblages, relative and total biomass, and species diversity; Table 1) and 275 abiotic conditions (bathymetry, organic matter; Table 2).

\section{$276 \quad 3.1 .1$. Biotic characteristics}

277 The habitat nearest to the mouth of the estuary, H1, was the habitat displaying the lowest 278 mean biomass $\left(\mathrm{F}_{(4,38)}=6.13 ; p=0.001\right)$. It was however the one displaying the highest 279 Simpson's diversity index (although marginally significant) along with the Haploops habitat 280 (H4). It was dominated by the suspension-feeder Cerastoderma edule (23\% of the total biomass; Table 1). H2 displayed mean values of biomass in comparison to other habitats. Its macrobenthic assemblage was mainly dominated by the polychaete Owenia fusiformis and the 283 deposit-feeders (69\% of the total biomass). H3 was similar to H2 in terms of functional 284 assemblage, i.e. dominated by a polychaete deposit-feeder, Sternaspis scutata, that accounted 285 for almost 30\% of the total biomass. The mean biomass in H3 was among the lowest with H1. The habitat H4 was quite different compared to the other four habitats of the bay. It was 287 largely dominated by suspension-feeders and mainly the species Haploops sp. (Table 1), a 288 tubiculous and gregarious amphipod considered as an autogenic engineer. It was also the 289 habitat displaying the greatest average biomass $\left(113.55 \mathrm{~g} / \mathrm{m}^{2}\right)$. The fifth habitat (H5) was a marine-influenced habitat that displayed relatively high values of biomass (average: 95.47 $\mathrm{g} / \mathrm{m}^{2}$ ). It was dominated at $48 \%$ by the bivalve Abra alba, a facultative suspension- and

292 deposit-feeder. The analyses of the benthic assemblages of the five habitats clearly showed 
the dominance of species belonging to the deposit- and suspension-feeder trophic guilds: H1

294 and H4 being dominated by suspension-feeders whereas the other three habitats being mainly 295 characterized by deposit-feeders.

296 3.1.2. Abiotic conditions

297 The comparison of the abiotic environment of the habitats suggested the importance of 298 bathymetry (adjusted $\left.\mathrm{R}^{2}=0.734, p<0.001\right)$ and organic matter $\left(\mathrm{OM}\right.$; adjusted $\mathrm{R}^{2}=0.319, p<$ 299 0.001) as forcing variables (Table 2). The distribution of the five habitats was closely related 300 to the bathymetric gradient: H1 located near the mouth of the estuary was the shallower 301 habitat (mean bathymetry $=5.9 \mathrm{~m}$ ) whereas H5, located far from the estuary was the deeper 302 habitat (mean bathymetry $=24 \mathrm{~m}$ ). The Haploops $(\mathrm{H} 4)$, located almost in the middle of the 303 bathymetric gradient displayed a significantly larger amount of organic matter (mean OM = $3045.9 \%$ dry weight) in comparison to the other habitats (Table 2).

\subsection{Habitat distinctiveness using $\delta^{13} \mathrm{C}$}

The $\delta^{13} \mathrm{C}$ values for most of the studied compartments (POM, invertebrate guilds, fish) 308 increased gradually from the river mouth (H1) to the marine habitats (H5), yet confirming the 309 spatial influence of the terrigeneous enrichment in the bay of Vilaine (Fig. 2). That increasing 310 relationship was observable for the $\delta^{13} \mathrm{C}$ POM signatures except for the Haploops habitat (H4)

311 which was ${ }^{13} \mathrm{C}$-depleted. Deposit-feeders showed significant differences in their $\delta^{13} \mathrm{C}$ 312 signatures among habitats $\left(\mathrm{F}_{(4,102)}=18.26 ; p=0.001\right)$ and these differences were attributed to $313 \mathrm{H} 1$ and H2 (habitats closest to the estuary) where deposit-feeders were ${ }^{13} \mathrm{C}$-depleted compared 314 to the marine habitats H3, H4 and H5 (Fig. 2). Suspension-feeders also showed clear 315 distinction among habitats that somehow followed the bathymetric gradient $\left(\mathrm{F}_{(4,64)}=8.60 ; p=\right.$ 316 0.001). Suspension-feeders from H1, H2 and H3 were ${ }^{13} \mathrm{C}$-depleted and significantly different 317 from those in $\mathrm{H} 4$ and H5 which displayed slightly enriched carbon signatures (Fig. 2). 
318 Carnivores showed significant differences in their $\delta^{13} \mathrm{C}$ signatures among habitats $\left(\mathrm{F}_{(3,20)}=\right.$ 4.27; $p=0.027)$ and these differences could be attributed to H1 where carnivores were carbon-depleted compared to the marine habitat H5 (Fig. 2).

The fish signatures varied respectively with the species (sole vs pouting) and the size class (G0 vs G1 sole). The range of variability of the sole $\delta^{13} \mathrm{C}$ signatures was larger than for the pouting (Fig. 2). Pouting $\delta^{13} \mathrm{C}$ signatures showed a decreasing relationship with depth. The $\delta^{13} \mathrm{C}$ values ranged from -15.7 to -16.3 for $\mathrm{G} 0$ and from -15.61 to -15.90 for $\mathrm{G} 1$. We believe that the decreasing trend is statistically significant probably due to an over power of the test (sample size $=228$ for G0 and 122 for G1). Ecologically speaking, the trend represents less than $0.6 \%$ variation. Young sole were only captured in H1, H2 and H3 and differences were found in their $\delta^{13} \mathrm{C}$ signatures $\left(\mathrm{F}_{(2,42)}=4.95 ; p=0.009\right) . \delta^{13} \mathrm{C}$ in $\mathrm{H} 1$ was $1 \%$ on average lower than in $\mathrm{H} 2$ ( $p=0.062$, very close to the significant threshold of 0.05 ). That confirms that the spatial distribution of that species age class is influenced by shallow depth. For G1 individuals of common sole, a significant difference among habitats was observed $\left(\mathrm{F}_{(3,158)}=\right.$ 7.85; $p=0.002): \delta^{13} \mathrm{C}$ signature increased with depth in the same way that fish prey signature increased due to the enhanced influence of marine inputs in deeper waters. The only exception to these sole trends was the signatures in H3 which displayed similar values to H1.

\subsection{Trophic interactions}

\subsubsection{Nitrogen signatures and trophic levels}

339 In general, $\delta^{15} \mathrm{~N}$ signatures of the benthic preys and fish were enriched at the mouth of the 340 river and depleted gradually moving towards the sea (Fig. 2). Interestingly, one compartment 341 did not follow that general pattern: G0 sole displayed similar stable $\delta^{15} \mathrm{~N}$ values (average $=$ 342 14.6) notwithstanding the habitat in which they were captured. 
344 Isotopic $\delta^{15} \mathrm{~N}$ signatures of POM displayed no significant difference between the five habitats,

$345\left(\mathrm{~F}_{(4,5)}=8.23 ; p=0.059\right)$. Deposit-feeders displayed significant differences in $\delta^{15} \mathrm{~N}$ among 346 habitats $\left(\mathrm{F}_{(4,102)}=12.73 ; p=0.001\right)$ and three groups of habitats could be distinguished. The 347 habitat close to the estuary (H1) which displayed N-enriched signatures, the habitats far from 348 the estuary (H3 and H5) which signatures were slightly lower than the ones in H1, and the 349 habitats $\mathrm{H} 2$ and $\mathrm{H} 4$ which displayed intermediate values of $\delta^{15} \mathrm{~N}$. The suspension-feeders also showed differences among habitats $\left(\mathrm{F}_{(4,64)}=15.01 ; p=0.001\right)$ as well as carnivores $\left(\mathrm{F}_{(3,20)}=\right.$ 9.74; $p=0.001): \delta^{15} \mathrm{~N}$ significantly decreased with increasing distance to the estuary. Using the results of stable isotopes, we can well discriminate carnivores from suspension- or deposit-feeders. The $\delta^{15} \mathrm{~N}$ signatures of carnivores are one trophic level higher than the $\delta^{15} \mathrm{~N}$ signatures of the other two invertebrate trophic guilds (mean $\delta^{15} \mathrm{~N}$ of carnivores $=13.66$; mean $\delta^{15} \mathrm{~N}$ of suspension-feeders $=10.42$, mean $\delta^{15} \mathrm{~N}$ of deposit-feeders $=10.45$ ). The stable isotope analyses did not allow to discriminate suspension- from deposit-feeders, as their food resources (e.g. suspended or sediment organic matter) probably display the same range of 358 isotopic signatures and/or some species (e.g. Abra alba, Owenia fusiformis, ...) from these two trophic guilds may display a great feeding plasticity between suspended and sediment organic matter.

As fish go through ontogenetic changes during their life and thus change their feeding habits, 362 we tested the difference in $\delta^{15} \mathrm{~N}$ values between the habitats for the two fish species by 363 looking at the Size*Habitat interaction (see Section 2.4 for details). The two-way ANOVAs 364 on fish $\delta^{15} \mathrm{~N}$ signatures showed a significant interaction for the common sole, suggesting that 365 the species likely fed in the different habitats on different food sources and that this relationship was influenced by the size of the fish $\left(\mathrm{F}_{(2,176)}=4.33 ; p=0.015\right)$. Sole G0 displayed enriched $\delta^{15} \mathrm{~N}$ values in habitats $\mathrm{H} 2$ and $\mathrm{H} 3$ in comparison to G1 in the same 
habitats (Fig. 2). G0 presented similar $\delta^{15} \mathrm{~N}$ values in all the sites where they were caught, and a signature equivalent to those observed for sole of G1 in H1 (Fig. 2). In opposition to the findings for the sole, no interaction was found for the pouting, meaning that the species fed on the same variety of preys in all the habitats whatever the size $\left(\mathrm{F}_{(3,262)}=1.28 ; p=0.28\right)$.

373 Calculation of the trophic position of the common sole and pouting confirmed the previous 374 findings on the $\delta^{15} \mathrm{~N}$ values. G0 and G1 soles displayed a different trophic level in H1, the G0 375 belonged to $2^{\text {nd }}$ consumers whereas G1 belonged to $3^{\text {rd }}$ consumers. The two size classes had the same trophic position in H2 and H3 (the habitats in which the G0 are found). G0 and G1 individuals of pouting presented the same trophic position notwithstanding the habitats in which they were captured (Fig. 2).

\subsubsection{Gut contents}

Gut content analyses confirmed the trophic position results for the two studied species (Fig. 3). The common sole displayed a different diet in H1 compared to the other habitats. The diet of that species also differed accordingly with its size in $\mathrm{H} 1$ (habitat*size: $\mathrm{F}_{(2,63)}=2.44 ; p=$ 0.009). Sole G0 preyed upon detritivores (e.g. Gammarus sp.) whereas sole G1 mainly preyed upon deposit-feeders. In the other habitats, common sole fed on carnivores (mainly Philine aperta) and suspension-feeders (e.g. Ampelisca sp. and small Acanthocardia echinata) notwithstanding its size. Pouting fed on similar preys notwithstanding the habitat in which they were sampled (Fig. 3), yet no difference was found in their diet in relation to habitats and size $\left(\mathrm{F}_{(4,98)}=1.47 ; p=0.098\right)$.

\section{Discussion}


This study showed that the bay of Vilaine functions as a mosaic of benthic habitats used by the fish. Isotopic values $\left(\delta^{13} \mathrm{C}\right.$ and $\left.\delta^{15} \mathrm{~N}\right)$ of the organisms within each habitat contributed to identify the spatial extent of the estuarine influence on the bay of Vilaine benthic food web, thereby suggesting the presence of potential spatial food web subsidies in that ecosystem. The large number of contiguous sampling sites allowed us to address the spatial relationships and the connectivity along the coastal-estuarine gradient.

Isotopic values of organisms common to all the habitats of the estuary showed a strong gradient from river to coastal habitats. The $\delta^{13} \mathrm{C}$ signature of benthic organisms varied accordingly to POM signature (except in H4): increasing gradually from the river mouth to the marine habitats. The spatial heterogeneity was in part due to the terrigeneous-derived organic matter which uptake was noticeable in several habitats, notably in the areas located at the river mouth. Numerous studies from estuarine ecosystems have highlighted estuarine signal in terms of organic matter supply in the benthic food web of coastal nursery grounds in Europe (Darnaude et al., 2004a; Vinagre et al., 2008; Kostecki et al., 2010), America (Simenstad and Wissmar, 1985; Deegan and Garritt, 1997) and Australia (Abrantes and Sheaves, 2008). In these studies, the magnitude of such $\delta^{13} \mathrm{C}$ depletion in the fish and invertebrate tissues reached values of $0.5 \%$ and $>1.5 \%$ in systems under low and high river discharge influence respectively (Darnaude, 2005; Connolly et al., 2009). In our study, the shift observed in $\delta^{13} \mathrm{C}$ in the fish and invertebrate tissues captured close to the mouth of the estuary and in the marine habitats were characteristic of large rivers $(>4 \%)$. The increasing enrichment gradient in $\delta^{13} \mathrm{C}$ from river to shelf was well reflected for species with low mobility (invertebrate carnivores, deposit- and suspension- feeders) and to a certain extent for benthic fish species strongly related to the substrate (e.g. common sole).

It is interesting to note that in $\mathrm{H} 4$, the habitat dominated by the ecosystem engineer Haploops sp., POM $\delta^{13} \mathrm{C}$ signatures did not follow the gradient observed in the other habitats and 
418 harboured the lowest value. This might be explained by the geochemical process performed 419 by ecosystem engineers that affect the flux and fate of carbon in estuaries (D'Andrea and 420 DeWitt, 2009). Indeed, benthic communities displaying active tube- or burrow-dwelling 421 infauna are often associated with elevated rates of carbon and nutrient remineralization and 422 increased advection of dissolved inorganic carbon and nitrogen from sediments (Kristensen, 423 2008). Physical engineers oxygenate sediments and mix labile organic matter into sediments, 424 thereby stimulating the activity of microbial communities responsible for recycling of carbon 425 and nutrients (Kristensen, 2008; D'Andrea and DeWitt, 2009). As we did not measure 426 biochemical fluxes in the Haploops habitat, these are of course hypothetical mechanisms that 427 remain to be verified.

Mean values of $\delta^{15} \mathrm{~N}$ for the benthic macrofauna and the fish (other that the sole G0) displayed a coastal-estuarine gradient where highest values were found close to the river mouth and declined as we move towards the shelf. This gradient disagrees with what is 432 commonly found in the literature: a $\delta^{15} \mathrm{~N}$ depletion from estuarine to marine waters (Wada, 433 1993; France, 1994). However, according to France (1995), $\delta^{15} \mathrm{~N}$ can vary substantially as a 434 result of anthropogenic inputs and biogeochemical processes (Owens, 1985). Thus agriculture 435 and/or industries may all contribute to enrich terrestrial waters in $\delta^{15} \mathrm{~N}$. It has been 436 demonstrated that coastal ecosystems receiving sewage discharges display particularly high $437 \delta^{15} \mathrm{~N}$ values (Gartner et al., 2002; Schlacher et al., 2005). Since the isotopic composition of 438 nitrogen can propagate throughout a local food web, organisms feeding in areas with high 439 anthropogenic nitrogen inputs can exhibit distinctive $\delta^{15} \mathrm{~N}$ values (Hansson et al., 1997). The 440 bay of Vilaine receives the waters of a $10800 \mathrm{~km}^{2}$ river watershed conveying inputs from 441 industry, urbanisation and agriculture. The annual flow of nutrients into the bay, evaluated to 44216000 tonnes of nitrogen and 1030 of phosphorus (Le Bris and Glemarec, 1995), might 
explain the high nitrogen values found in the POM and in the organisms close to the river 444 mouth.

Nitrogen rich effluents from the river might enhance the primary production, the productivity of invertebrate preys and be favourable to fish that use the areas as nursery ground (Darnaude et al., 2004a). Using stable isotopes in the bay of Vilaine, Kostecki et al. (2010) aimed to determine the potential mechanisms of the "wet year nursery expansion" hypothesis stated earlier by (Le Pape et al., 2003a). According to that hypothesis, benthic macrofauna would benefit from the nitrogen-enriched terrestrial material sinking from plumes during years of high river flow. By food web propagation, the benthic productivity would enhance fish productivity and provide suitable food for young fish and notably the juveniles of common sole. In that context, the larger the volume of river discharge (i.e. observed in wet years) the further distance the terrestrial material will be carried out, thereby increasing the spatial extent of productive areas (Connolly et al., 2009). Kostecki et al. (2010) showed that during the wet years $\delta^{13} \mathrm{C}$ signatures of the G0 sole were typical to those influenced by terrestrial inputs in 458 the habitat that spatially corresponded to H1 (our habitat near the mouth of the estuary). We 459 corroborated their result and hypothesized that the spatial effect of the Vilaine terrestrial 460 inputs can be observable far beyond Kostecki’s outer estuary sampling sites, that is up to our H3 (muddy habitat with depth $\leq 20 \mathrm{~m}$ ). That extent also corresponds to the limit at which no young-of-the-year of the sole was captured and to recent habitat suitability models developed 463 for the juvenile soles (Trimoreau et al. submitted).

Studies on coastal food webs often ignore the size structure within species. However, fish may undergo three to four ontogenetic changes during their life cycle and these size-specific 
availability (Werner and Gilliam, 1984). The combined use of stable isotopes, gut content analyses and calculation of the trophic position have provided a detailed picture of the spatialized productivity and trophic interactions that likely occur in the bay of Vilaine. This was notably observed in the habitat near the mouth of the estuary which displayed a supplementary trophic level in comparison to the other habitats. The isotopic signatures and gut content analyses in that habitat (H1) revealed that the common sole displayed size-based diet changes eating prey from different trophic guilds. Juveniles of that species preyed primarily upon detritivore species (mainly Gammarus sp.). In the Gironde, another French estuary, Pasquaud et al. (2008) found that polychaetes and Gammarus were the main food items of the common sole. These authors did not account however for the potential change of diet according to the size of the individuals. In our study, as the sole grew up, dietary changes occurred involving increased contributions of deposivore preys. Sole G1 displayed similar patterns to G0 but with less variability in $\delta^{13} \mathrm{C}$ signatures $(<1.5 \%$ for $\mathrm{G} 1$ in comparison to $>$ 2\%o for G0), thereby suggesting an increased in habitat connectivity (or habitat use) as the sole grew older.

The absence of any spatial structure in $\delta^{15} \mathrm{~N}$ signatures of the G0 common sole confirms our 484 precedent findings with the $\delta^{13} \mathrm{C}$ and suggests strong feeding plasticity and opportunism for 485 that age class. Opportunistic feeding was also supported by the gut content analyses which clearly show a large prey spectrum in the habitats they use (H1 vs H2 and H3). Studies of the feeding ecology of juvenile flatfishes highlighted opportunistic feeding by many species 488 including the common sole (Lasiak and McLachlan, 1987; Beyst et al., 1999; Cabral, 2000). 489 Feeding flexibility in estuaries and coastal zones allows to exploit peaks of available preys 490 when fishes often need to share resources (Ley et al., 1994). Our conclusions regarding the 491 feeding flexibility of the common sole is in agreement with Leakey (2008a, 2008b) who also 492 found such feeding characteristic at the population level. According to these authors, G0 of 
493 sole consumed both estuarine and coastal preys whereas older fish mainly consumed marine 494 food items.

495 The diet of the sole mimics the abundance distribution of the species across the estuarine496 coastal gradient: G0 remaining in coastal habitats during their first year and move towards 497 offshore habitats at the end of their first year (Costa et al., 2002). This marine intrusion may 498 indeed explain the carbon isotopic signatures of the G1 sole, reflecting the use of marine 499 sources. Gut content analyses revealed that in H2 and H3, common sole fed predominantly on 500 carnivorous preys. However, as the isotopic signatures of these preys were similar to those of 501 the soles, no such trophic interaction could be confirmed. This result might be explained by 502 the fact that the carnivore prey observed in sole gut contents were mainly composed of 503 Philine aperta (respectively $89 \%$ and $96 \%$ in $\mathrm{H} 2$ and $\mathrm{H} 3$ ) but unfortunately no isotope 504 samples of this species could be obtained in the present study. $\delta^{15} \mathrm{~N}$ signatures of $P$. aperta 505 were assessed in another study conducted in the bay of Vilaine (in habitats corresponding to H2 and H3) and in another French nursery (the bay of Concarneau) by Houssin (2010). Signatures of these species were close to $10 \%$, a value coherent to those expected here.

508 As opposed to common sole, pouting did not show any size-based feeding plasticity (i.e. low 509 variability in $\delta^{13} \mathrm{C}$ signatures for two age classes). The G0 and G1 of that species used indifferently the different habitats (as displayed by the $\delta^{13} \mathrm{C}$ values) but showed low feeding 511 plasticity across and within each habitat (as displayed by the $\delta^{15} \mathrm{~N}$ values). These results 512 suggest that this species easily moves across the habitats, thereby integrating the various $\delta^{13} \mathrm{C}$ 513 signatures of low mobile preys belonging to these habitats. Similar findings were described in 514 the Thames estuary (Leakey et al., 2008a) where estuarine-caught whiting (another gadid species) had intermediate $\delta^{13} \mathrm{C}$ signatures $(\approx-18 \%$ ), suggesting that whiting moved and fed 516 on preys from estuarine and coastal waters. Similar results were also observed in Netherlands 517 where juveniles of pouting used both estuarine and coastal habitats as nursery grounds 
518 (Hamerlynck and Hostens, 1993). According to Power et al. (2002), salinity would be the major forcing factor explaining the variability of pouting abundance and to a lesser extent food resources. For Gadidae in general, environmental factors such as temperature and salinity seem to have the strongest influence on the species distribution (Power et al., 2002). These comparisons of our results with those from other coastal areas (Gironde and Thames estuaries, South-west of Netherlands, bay of Concarneau) or other functionally similar benthic

524 and demersal species (i.e. senegalese sole or whiting) make us confident that our findings might be generalized to other temperate coastal areas and species that present similar life strategies.

Our study was conducted during summer time, when the influence of the river flow is the 529 least. The strength of the terrestrial signal in coastal food webs increases after periods of high river flow i.e. during autumn and winter for the present study (Bănaru et al., 2007). At this period, trophic subsidies of benthic compartments by river discharge are expected to be firmly installed. In that context, we believe that it is very unlikely that the season of our study

533 influence the spatial patterns that we observed in here. Indeed, the seaward $\delta^{13} \mathrm{C}$ gradient in 534 the bay of Vilaine during winter is also apparent, only its amplitude differ (Mortillaro et al., unpublished data). In another ecosystem, França et al. (2011), observed similar results when studying two estuarine systems of the Portuguese coast. They concluded that seasonal 537 differences were not pronounced enough to produce significant dissimilarities in the species 538 isotopic signatures and the estuarine functioning between the two seasons.

540 Beside the Haploops habitat, the macrozoobenthic habitats defined in our study are generally 541 common to all open shallow muddy estuarine area under the influence of freshwater inflows 542 (e.g. Seine: Elkaim et al., 1982; Dauvin et al., 2006). We are confirming the general pattern 
observed in these ecosystems, that terrestrial inputs are structuring coastal and estuarine food

544 webs. Given that the bay of Vilaine offers different habitats for the G0 of several species,

545 including the common sole (Le Pape et al., 2003b) and that strong environmental changes are

546 actually occurring in these habitats $\left(+1.5^{\circ} \mathrm{C}\right.$ in temperature and +2 in salinity; Kopp et al.,

547 Submitted), our study raises important questions: Are all the habitats close to the river mouth

548 equivalent in terms of G0 production? Will the environmental changes affect the species

549 distribution? What is the relative importance of the trophic interactions versus the physical

550 environment in all the described habitats? Do species inhabiting these habitats display similar

551 growth rates? In the context of multiple coastal uses and coastal management, these are

552 crucial questions that remain to be answered.

553

\section{References}

555

556 Abrantes, K., Sheaves, M., 2008. Incorporation of terrestrial wetland material into aquatic food webs in a tropical estuarine wetland. Estuar. Coast. Shelf. Sci. 80, 401-412.

558 Anderson, M.J., 2001. A new method for non-parametric multivariate analysis of variance.

$559 \quad$ Austral Ecol. 26, 32-46.

560 Appeltans, W., Bouchet, P., Boxshall, G.A., Fauchald, K., Gordon, D.P., Hoeksema, B.W., Poore, G.C.B., van Soest, R.W.M., Stöhr, S., Walter, T.C., Costello, M.J., 2011. World Register of Marine Species. Available at www.marinespecies.org [accessed on October 2012].

Bănaru, D., Harmelin-vivien, M., Gomoiu, M.-T., Onciu, T.-M., 2007. Influence of the Danube River inputs on $\mathrm{C}$ and $\mathrm{N}$ stable isotope ratios of the Romanian coastal waters and sediment (Black Sea). Mar. Poll. Bull. 54, 1385-1394. 
Baird, D., Christian, R.R., Peterson, C.H., Johnson, G.A., 2004. Consequences of hypoxia on estuarine ecosystem function: Energy diversion from consumers to microbes. Ecol. Appl. 14, 805-822.

Beck, M.W., Heck, K.L., Able, K.W., Childers, D.L., Eggleston, D.B., Gillanders, B.M., Halpern, B., Hays, C.G., Hoshino, K., Minello, T.J., Orth, R.J., Sheridan, P.F., Weinstein, M.R., 2001. The identification, conservation, and management of estuarine and marine nurseries for fish and invertebrates. Bioscience 51, 633-641.

Beyst, B., Cattrijsse, A., Mees, J., 1999. Feeding ecology of juvenile flatfishes of the surf zone of a sandy beach. J. Fish. Biol. 55, 1171-1186.

Brischoux, F., Bonnet, X., Cherel, Y., Shine, R., 2011. Isotopic signatures, foraging habitats and trophic relationships between fish and seasnakes on the coral reefs of New Caledonia. Coral Reefs 30, 155-165.

Buckland, S.T., Magurran, A.E., Green, R.E., Fewster, R.M., 2005. Monitoring change in biodiversity through composite indices. Philos. Trans. R. Soc. B-Biol. Sci. 360, 243254.

Cabral, H.N., 2000. Comparative feeding ecology of sympatric Solea solea and S. senegalensis, within the nursery areas of the Tagus estuary, Portugal. J. Fish. Biol. 57, 1550-1562.

Colwell, R.K., 2009. Biodiversity: Concepts, Patterns, and Measurement, in: Levin, S.A. (Ed.), The Princeton Guide to Ecology. Princeton University Press, Princeton, NJ., pp. 257-263.

588 Connolly, R.M., Schlacher, T.A., Gaston, T.F., 2009. Stable isotope evidence for trophic 589 subsidy of coastal benthic fisheries by river discharge plumes off small estuaries. Mar. Biol. Res. 5, 164-171. 
Conover, W.J., 1999. Practical non-parametric statistics, third ed. John Wiley and Sons, New York.

Costa, M.J., Cabral, H.N., Drake, P., Economou, A.N., Fernandez-Delgado, C., Gordo, L., Marchand, J., Thiel, R., 2002. Recruitment and production of commercial species in estuaries, in: Elliott M., Hemingway, K.L. (Eds), Fishes in Estuaries. Blackwell Science LTD, Oxford, pp. 54-123.

Costanza, R., d'Arge, R., de Groot, R., Farber, S., Grasso, M., Hannon, B., Limburg, K., 598 Naeem, S., O'Neill, R.V., Paruela, J., Raskin, R.G., Sutton, P., van den Belt, M., 1997. The value of the world's ecosystem services and natural capital. Nature 387, 253-260.

D'Andrea, A.F., DeWitt, T.H., 2009. Geochemical ecosystem engineering by the mud shrimp Upogebia pugettensis (Crustacea: Thalassinidae) in Yaquina Bay, Oregon: Densitydependent effects on organic matter remineralization and nutrient cycling. Limnol. Oceanogr. 54, 1911-1932.

Darnaude, A.M., 2005. Fish ecology and terrestrial carbon use in coastal areas: implications for marine fish production. J. Anim. Ecol. 74, 864-876.

Darnaude, A.M., Salen-Picard, C., Harmelin-Vivien, M.L., 2004a. Depth variation in terrestrial particulate organic matter exploitation by marine coastal benthic

Darnaude, A.M., Salen-Picard, C., Polunin, N.V.C., Harmelin-Vivien, M.L., 2004b. Trophodynamic linkage between river runoff and coastal fishery yield elucidated by stable isotope data in the Gulf of Lions (NW Mediterranean). Oecologia 138, 325-332. estuarine benthic and suprabenthic communities resulting from the development of harbour infrastructure. Mar. Pol. Bull. 53, 80-90. 
616 Deegan, L.A., Garritt, R.H., 1997. Evidence for spatial variability in estuarine food webs. Mar. Ecol. Progr. Ser. 147, 31-47.

618 De Niro, M.J., Epstein, S., 1978. Influence of diet on distribution of carbon isotopes in animals. Geochim. Cosmochim. Acta 42, 495-506.

Dolcinar, S., Grabler, K., Mazanec, J.A., 1999. Analyzing Destination Images: a Perceptual Charting Approach,. Available at http://ro.uow.edu.au/commpapers/310 [accessed on October 2011].

Elkaim, B., Ibanez, F., Proniewski, F., 1982. Le benthos subtidal de l'estuaire de la Seine: analyse statistique des peuplements. J. Exp. Mar. Biol. Ecol. 64, 231-252.

Faith, D.P., Minchin, P.R., Belbin, L., 1987. Compositional dissimilarity as a robust measure of ecological distance. Vegetatio 69, 57-68.

Fauchald, K., Jumars, P.A., 1979. The diet of worms: a study of polychaete feeding guilds. Oceanogr. Mar. Biol. Ann. Rev. 17, 193-284.

França, S., Vasconcelos, R.P., Tanner, S., Máguas, C., Costa, M.J., Cabral, H.N., 2011. Assessing food web dynamics and relative importance of organic matter sources for Res. 72, 204-215.

France, R., 1994. Nitrogen isotopic composition of marine and freshwater invertebrates. Mar. Ecol. Prog. Ser. 115, 205-207.

France, R., 1995. Stable nitrogen isotopes in fish: Literature synthesis on the influence of ecotonal coupling. Estuar. Coast. Shelf Sci. 41, 737-742.

Fry, B., 2008. Open bays as nurseries for Louisiana brown shrimp. Estuaries Coasts 31, 776638 789. 
Gartner, A., Lavery, P., Smit, A.J., 2002. Use of delta N-15 signatures of different functional forms of macroalgae and filter-feeders to reveal temporal and spatial patterns in sewage dispersal. Mar. Ecol. Prog. Ser. 235, 63-73.

Gonzalez, L., Manly, B.F.J., 1998. Analysis of variance by randomization with small data sets. Environmetrics 9, 53-65.

Hamerlynck, O., Hostens, K., 1993. Growth, feeding, production, and consumption in 0group bib (Trisopterus luscus L.) and whiting (Merlangius merlangus L.) in a shallow coastal area of the South-west Netherlands. ICES J. Mar. Sci. 50, 81-91.

Hansson, S., Hobbie, J.E., Elmgren, R., Larsson, U., Fry, B., Johansson, S., 1997. The stable nitrogen isotope ratio as a marker of food-web interactions and fish migration. Ecology 78, 2249-2257.

Hily, C., Bouteille, M., 1999. Modifications of the specific diversity and feeding guilds in an intertidal sediment colonized by an eelgrass meadow (Zostera marina) (Brittany, France). C.R. Biol. 322, 1121-1131.

Ho, C.-T., Fu, Y.-C., Sun, C.-L., Kao, S.-J., Jan, R.-Q., 2009. Plasticity of feeding habits of two Plectroglyphidodon damselfishes on coral reefs in Southern Taiwan: Evidence from stomach content and stable isotope analyses. Zool. Stud. 48, 649-656.

Houssin, L., 2010. Diversité et structure trophique de la macrofaune chalutée associée aux habitats à Haploops spp. de Bretagne. MSc thesis, Université de Bretagne Occidentale - Institut Universitaire Européen de la Mer, Brest (France).

Islam, M.S., Tanaka, M., 2006. Spatial variability in nursery functions along a temperate estuarine gradient: role of detrital versus algal trophic pathways. Can. J. Fish. Aquat. Sci. 63, 1848-1864.

Josefson, A.B., Conley, D.J., 1997. Benthic response to a pelagic front. Mar. Ecol. Progr. Ser. $147,49-62$. 
Kostecki, C., Le Loc'h, F., Roussel, J.M., Desroy, N., Huteau, D., Riera, P., Le Bris, H., Le Pape, O., 2010. Dynamics of an estuarine nursery ground: the spatio-temporal relationship between the river flow and the food web of the juvenile common sole (Solea solea, L.) as revealed by stable isotopes analysis. J. Sea Res. 64, 54-60.

Kristensen, E., 2008. Mangrove crabs as ecosystem engineers with emphasis on sediment processes. J. Sea Res. 59, 30-43.

Largier, J.L., 1993. Estuarine fronts - How important are they. Estuaries 16, 1-11.

Lasiak, T., McLachlan, A., 1987. Opportunistic utilization of mysid shoals by surf-zone teleosts. Mar. Ecol. Progr. Ser. 37, 1-7.

Le Bris, H., Glémarec, M., 1995. Macrozoobenthic communities of an oxygen undersaturated coastal ecosystem: The Bay of Vilaine (Southern Brittany). Oceanologica Acta 18, 573-581.

Le Pape, O., Chauvet, F., Desaunay, Y., Guerault, D., 2003a. Relationship between interannual variations of the river plume and the extent of nursery grounds for the common sole (Solea solea, L.) in Vilaine Bay. Effects on recruitment variability. J. Sea Res. 50, 177-185.

Le Pape, O., Chauvet, F., Mahevas, S., Lazure, P., Guerault, D., Desaunay, Y., 2003b. Quantitative description of habitat suitability for the juvenile common sole (Solea solea, L.) in the Bay of Biscay (France) and the contribution of different habitats to the adult population. J. Sea Res. 50, 139-149.

Le Pape, O., Modéran, J., Beaunée, G., Riera, P., Nicolas, D., Savoye, N., Harmelin-Vivien, M., Darnaude, A.M., Brind'Amour, A., Le Bris, H., Cabral, H., Vinagre, C., Pasquaud, S., França, S., Kostecki, C., 2013. Sources of organic matter for flatfish juveniles in coastal and estuarine nursery grounds: a meta-analysis for the common sole (Solea solea) in contrasted systems of Western Europe. J. Sea Res. 75, 85-95. 
Leakey, C.D.B., Attrill, M.J., Jennings, S., Fitzsimons, M.F., 2008a. Retrospective 690

691

692 quantification of estuarine feeding activity by coastally caught marine fishes. J. Sea Res. 60, 210-214.

Leakey, C.D.B., Attrill, M.J., Jennings, S., Fitzsimons, M.F., 2008b. Stable isotopes in juvenile marine fishes and their invertebrate prey from the Thames Estuary, UK, and adjacent coastal regions. Estuar. Coast. Shelf Sci. 77, 513-522.

Ley, J.A., Montague, C.L., McIvor, C.C., 1994. Food habits of mangrove fishes: a comparison along estuarine gradients in Northeastern Florida Bay. Bull. Mar. Sci. 54, 881-899.

Lorrain, A., Savoye, N., Chauvaud, L., Paulet, Y.M., Naulet, N., 2003. Decarbonation and preservation method for the analysis of organic $\mathrm{C}$ and $\mathrm{N}$ contents and stable isotope ratios of low-carbonated suspended particulate material. Anal. Chim. Acta 491, 125133.

Maslowski, J., 2003. Effects of trophic conditions on benthic macrofauna in the vicinity of the River Swina mouth (Pomeranian Bay; southern Baltic Sea). Oceanologia 45, 41-52.

McClelland, J.W., Valiela, I., Michener, R.H., 1997. Nitrogen-stable isotope signatures in estuarine food webs: A record of increasing urbanization in coastal watersheds. Limnol. Oceanogr. 42, 930-937.

Merayo, C.R., Villegas, M.L., 1994. Age and growth of Trisopterus luscus (Linnaeus, 1758) (Pisces, Gadidae) off the coast of Asturias. Hydrobiologia 281, 115-122.

Mérigot, B., Letourneur, Y., Lecomte-Finiger, R., 2007. Characterization of local populations of the common sole Solea solea (Pisces, Soleidae) in the NW Mediterranean through otolith morphometrics and shape analysis. Mar. Biol. 151, 997-1008. 
Minagawa, M., Wada, E., 1984. Stepwise enrichment of ${ }^{15} \mathrm{~N}$ along food chains: further evidence and the relation between ${ }^{15} \mathrm{~N}$ and animal age. Geochim. Cosmochim. Acta 48, 1135-1140.

Nielsen, E., Richardson, K., 1996. Can changes in the fisheries yield in the Kattegat (19501992) be linked to changes in primary production? ICES J. Mar. Sci. 53, 988-994.

Oana, S., Deevey, E.S., 1960. Carbon 13 in lake waters, and its possible bearing on paleolimnology. Am. J. Sci. 256-A, 253-272.

Owens, N.J.P., 1985. Variations in the natural abundance of ${ }^{15} \mathrm{~N}$ in estuarine suspended particulate matter - a specific indicator of biological processing. Estuar. Coast. Shelf Sci. 20, 505-510.

Pasquaud, S., Elie, P., Jeantet, C., Billy, I., Martinez, P., Girardin, M., 2008. A preliminary investigation of the fish food web in the Gironde estuary, France, using dietary and stable isotope analyses. Estuar. Coast. Shelf Sci. 78, 267-279.

Peterson, B.J., Fry, B., 1987. Stable isotopes in ecosystem studies. Ann. Rev. Ecol. Syst. 18, 293-320.

Pinnegar, J.K., Polunin, N.V.C., 1999. Differential fractionation of delta C-13 and delta N-15 among fish tissues: implications for the study of trophic interactions. Funct. Ecol. 13, 225-231.

Post, D.M., 2002. Using stable isotopes to estimate trophic position: Models, methods, and assumptions. Ecology 83, 703-718.

Post, D.M., Layman, C.A., Arrington, D.A., Takimoto, G., Quattrochi, J., Montaña, C.G., 2007. Getting to the fat of the matter: models, methods and assumptions for dealing with lipids in stable isotope analysis. Oecologia 152, 179-189. 
Power, M., Attrill, M.J., Thomas, R.M., 2002. Environmental influences on the long-term fluctuations in the abundance of gadoid species during estuarine residence. J. Sea Res. 47, 185-194.

R Development Core Team, 2008. R: A language and environment for statistical computing R Foundation for Statistical Computing, Vienna, Austria. ISBN 3-900051-07-0, available at http://www.R-project.org.

Ray, G.C., 2005 Connectivities of estuarine fishes to the coastal realm. Estuar. Coast. Shelf Sci. 64, 18-32.

Rosenberg, R., 1993. Suspension feeding in Abra alba (Mollusca). Sarsia 78, 119-121.

Salen-Picard, C., Darnaude, A.M., Arlhac, D., Harmelin-Vivien, M.L., 2002. Fluctuations of macrobenthic populations: a link between climate-driven river run-off and sole fishery yields in the Gulf of Lions. Oecologia 133, 380-388.

Schlacher, T.A., Liddell, B., Gaston, T.F., Schlacher-Hoenlinger, M., 2005. Fish track wastewater pollution to estuaries. Oecologia 144, 570-584.

Simenstad, C.A., Wissmar, R.C., 1985. Delta C13 evidence of the origins and fates of organic carbon estuarine and nearshore food webs. Mar. Ecol. Progr. Ser. 22, 141-152.

Vinagre, C., Salgado, J., Costa, M.J., Cabral, H.N., 2008. Nursery fidelity, food web interactions and primary sources of nutrition of the juveniles of Solea solea and Ssenegalensis in the Tagus estuary (Portugal): A stable isotope approach. Estuar. Coast. Shelf Sci. 76, 255-264.

Wada, E., Kabaya, Y., Kurihara, Y., 1993. Stable isotopic structure of aquatic ecosystems. J. Biosci. 18, 483-499.

Ward Jr, J.H., 1963. Hierarchical grouping to optimize an objective function. J. Am. Stat. Assoc. 58, 236-244. 
759 Werner, E.E., Gilliam, J.F., 1984. The ontogenetic niche and species interactions in structured populations. Ann. Rev. Ecol. Syst. 15, 393-425.

761 
761 Table 1. Summary of the different biotic variables in each habitat. Mean values and standard

762 deviations (in brackets) are given.

$\begin{array}{lccccc} & \text { Habitat } 1 & \text { Habitat } 2 & \text { Habitat } 3 & \text { Habitat } 4 & \text { Habitat 5 } \\ \text { Dominant species (in biomass) } & \text { Cerastoderma } & \text { Owenia } & \text { Sternaspis } & \text { Haploops sp. } & \text { Abra alba } \\ & \text { edule } & \text { fusiformis } & \text { scutata } & & \\ \left.\text { Total biomass (g/ } \mathrm{m}^{2}\right) & 14.22(20.79) & 78.87(53.89) & 32.33(14.63) & 113.55(72.45) & 95.47(39.17) \\ \text { Inverse Simpson' index } & 2.63(2.23) & 1.74(0.72) & 1.63(0.81) & 3.30(2.94) & 1.83(0.59) \\ \text { Guild relative biomass (\%) } & & & & & \\ \text { Carnivores } & 8.80 & 12.56 & 11.95 & 1.94 & 5.78 \\ \text { Detritivores } & 0.050 & 0.01 & 0.04 & 0.00 & 0.00 \\ \text { Deposit- feeders } & 40.44 & 69.43 & 50.21 & 7.38 & 79.66 \\ \text { Suspension-feeders } & 46.82 & 17.99 & 37.47 & 90.68 & 14.35 \\ \text { Scavengers } & 3.89 & 0.01 & 0.33 & 0.00 & 0.21\end{array}$

763

764 
764 Table 2. Summary of the different abiotic variables in each habitat. Mean values and standard

765 deviations (in brackets) are given.

$\begin{array}{lccccc} & \text { Habitat 1 } & \text { Habitat 2 } & \text { Habitat 3 } & \text { Habitat 4 } & \text { Habitat 5 } \\ \text { Bathymetry (m) } & 5.91(0.61) & 9.30(1.79) & 13.64(3.80) & 18.55(1.95) & 24.00(6.46) \\ \text { Organic matter (\% dry weight) } & 5.81(2.63) & 5.80(2.37) & 7.92(2.21) & 10.46(0.87) & 6.60(1.22) \\ \text { Sediment type } & \text { Mud } & \text { Mud and sand } & \text { Mud } & \text { Consolidated } & \text { Mud and sand } \\ & & & & \text { mud } & \\ \text { Number of hauls } & 7 & 10 & 9 & 5 & 12\end{array}$

766

767

768 
Figure captions

769

770 Fig. 1. Bathymetric map of the bay of Vilaine in the northern Bay of Biscay and geographic

771 position of the sampling sites. $1,2,3,4$ and $5=$ habitats. Habitats were defined using a

772 hierarchical cluster analysis on a matrix of invertebrates biomass combined with morpho-

773 sedimentary data.

774

775 Fig. 2. $\delta^{13} \mathrm{C}$ and $\delta^{15} \mathrm{~N}$ values (mean $\pm \mathrm{SD}$ ) for POM, carnivores, deposit- and suspension-

776 feeders, and fish in the five described habitats. The fish were separated in two age classes (G0

777 for the young-of-the-year and G1 for age 1 individuals; see Material and Methods for details).

778 Prey were classified in trophic guilds. Number of individuals of fish and preys in the different 779 habitats are indicated (N).

780

781 Fig. 3. Relative abundance (\%) of the different trophic guilds in the gut contents of common 782 sole and pouting in the 5 studied habitats (0: G0, 1: G1). No sole was captured in the 783 Haploops habitat (H4), nor any sole G0 was observed in the deeper habitat (H5). Prey items 784 in gut contents were classified in trophic guilds, only scavengers are absent from gut contents. 785 Numbers of gut contents analysed are given above the barplot. 


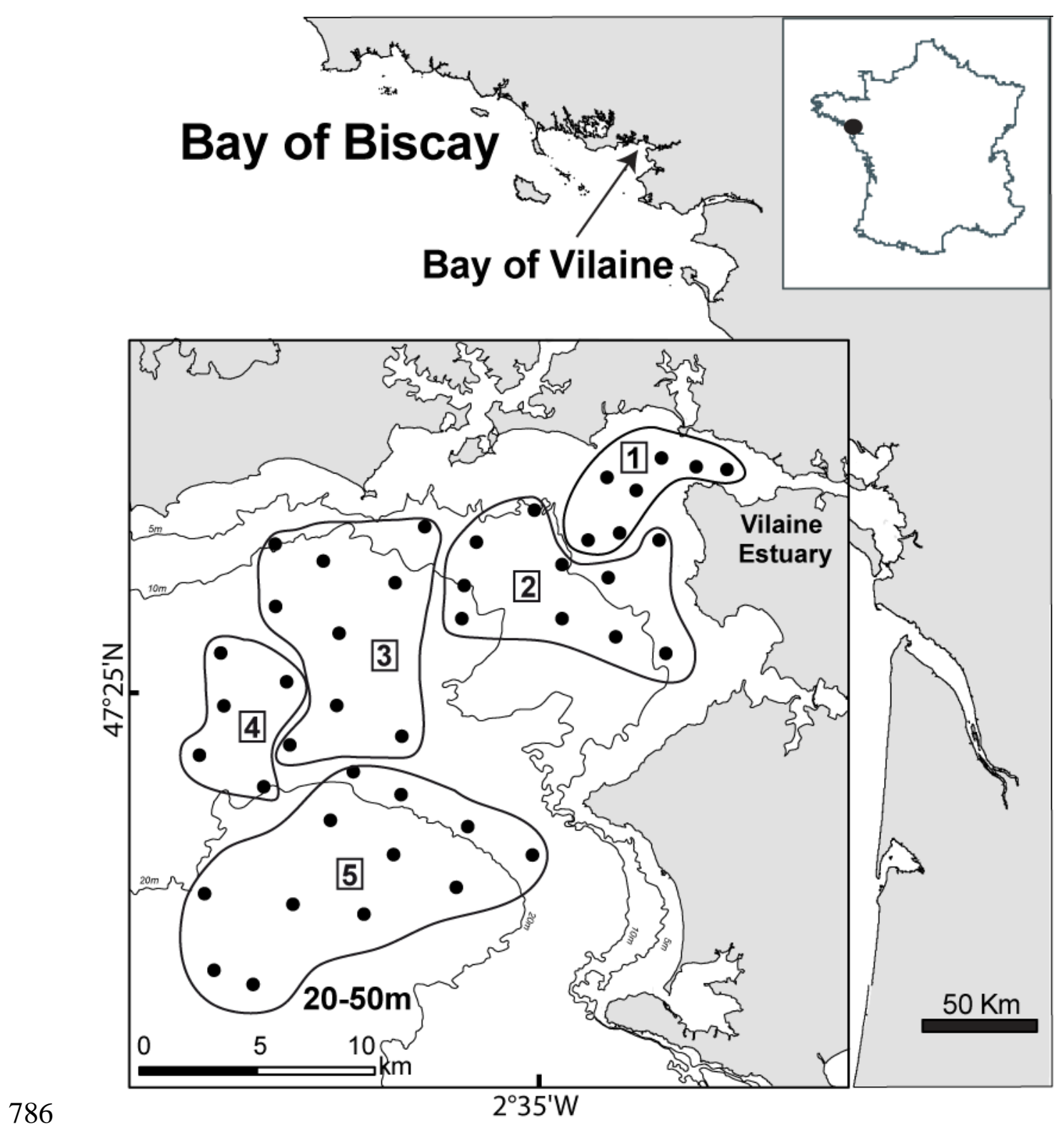

$787 \quad$ Figure 1

788 


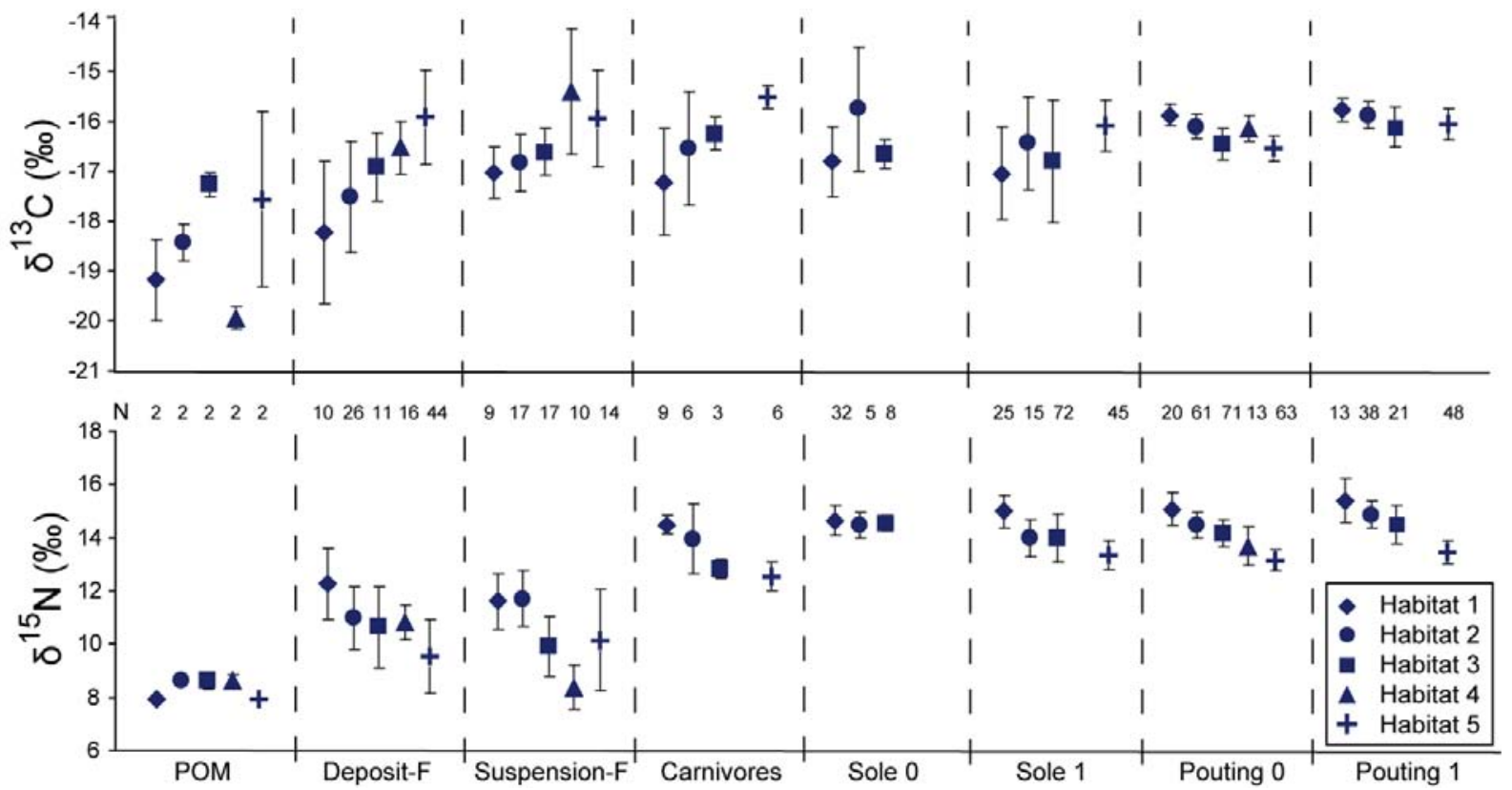

$789 \quad$ Figure 2 


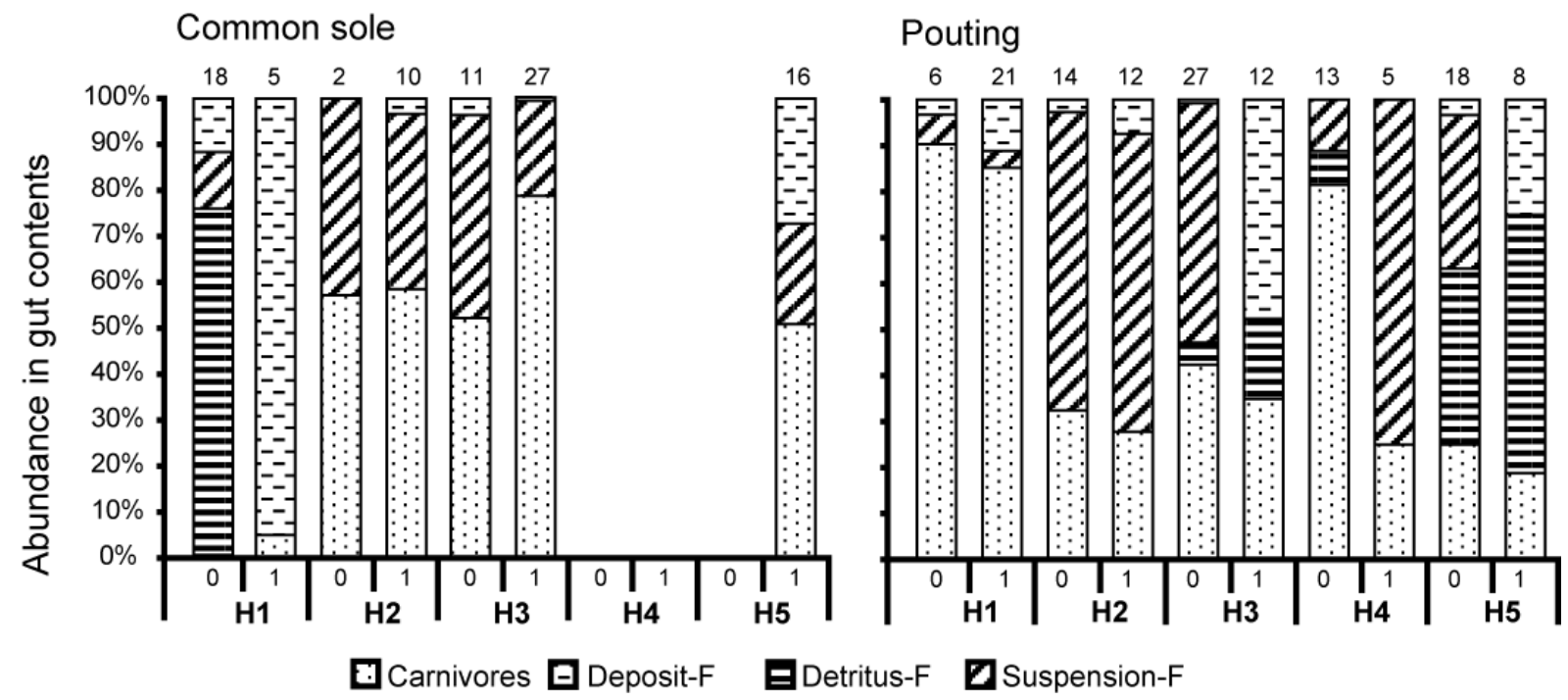

790

$791 \quad$ Figure 3 